\title{
An Analysis on the Calculation of the Cost-Based Interconnection Retail Tariff at Telecommunication Industry in Indonesia
}

\author{
Zara Sita N. \\ Fakultas Ekonomi \& Bisnis Departemen Akuntansi - Universitas Padjadjaran \\ (Jl. Dipati Ukur No. 35, Bandung) \\ zara_sita@yahoo.com \\ Dede Abdul Hasyir \\ Fakultas Ekonomi \& Bisnis Departemen Akuntansi - Universitas Padjadjaran \\ (Jl. Dipati Ukur No. 35, Bandung) \\ dede.hasyir@fe.unpad.ac.id
}

\begin{abstract}
Abstrak
Kajian ini bertujuan untuk mengeksplorasi dan menjelaskan bagaimana sebuah aplikasi sistem biaya dipilih dan digunakan untuk menentukan suatu model tarif interkoneksi pada sebuah jaringan seluler. Usaha ini dilakukan dalam rangka merumuskan solusi atas penentuan tarif retail, yang pada akhirnya akan menjadi harga jual yang ditetapkan bagi konsumen. Formulasi tarif interkoneksi berbasis biaya diatur oleh pemerintah Indonesia melalui lembaga yang bernama Badan Regulasi Tarif Indonesia.

Secara khusus, studi ini bertujuan untuk mengetahui apakah implementasi regulasi telah dijalankan dengan baik oleh salahsatu penyedia layanan telekomunikasi di Indonesia, yaitu Indosat. Penelitian ini, yang dilakukan dengan pendekatan kualitatif, juga ditujukan untuk mengetahui pengaruh penerapan regulasi pada penetapan tarif retail yang dilakukan oleh penyedia jasa seluler.
\end{abstract}

Kata Kunci: Interkoneksi; Pembebanan Biaya Jasa; Penelitian Kualitatif; Tarif Retail

\section{Background}

Interconnection between network operators in a competitive market is essential for delivering services to customers (Verbrugge et. Al., 2006). Then the interconnection cost has become an important part in the calculation of telecommunication tariff. "Infocom" Ministry Regulation No. 8 Year 2006 about Interconnection mentions a shifting on interconnection tariff system from revenue sharing to cost-based with the spirit of transparency, non-discrimination, and time-framed. The regulation endorses Indonesian celullar providers to adjust their interconnection tariff, which will also be reflected on their retail tariff to the customers. 
In practise, interconnection sytem is not as ideal as its normative. There are many constraints faced by the operators on the implementations, both technical and non-technical. As an existing provider that has a number of customers, major providers have a power to create the interconnection systems, as it expect to. On the other hand, new players do not own a wide infrastructure to perform their services, and their customer basis are also not as big as the major providers. They tend to realize and accept the conditions created ny major operators. This imbalance condition is not only happened in Indonesia, but also in many other countries (Harbord et. al., 2010).

The problem of imbalance power is solved by the Indonesian Government. "Infocom" Ministry Regulation No. 8 Year 2006 about Interconnection asks every operator to release a List of Interconnection Offer (LIO). For major operators, their LIO must be approved by a regulatory body called Badan Regulasi Telekomunikasi Indonesia (BRTI) before they use their LIO as a basis for interconnection agreement with other operators. BRTI itself is established to protect the public interest as telecommunication users and to create a healthy environment in the competition of telecommunication industry. With this approval mechanism, it is expected that interconnection tarif used by major operators can be controlled by the Government.

The establishment of new interconnection system is also dedicated to bridge any litigation problems between operators, and finally to decrease the telecommunication tariff to customers. A chance of disobey the rule is indicated. This is caused by at least two possibilities. Firstly, the rule is not easy to be implemented. Secondly, the major operators are not ready to implement it and might not possess a strong willingness to change their costing systems. The last possibility is might caused by organizational and network complexity. In the other hand, the first possibility is seem to be hard to understand, why the BRTI accept the formula created by consultant without doing a simulation through a representative data sampel that reflects the validity of interconnection traffic population. The reason that the formula has been widely used in many countries such as U.K., Australia, Hongkong SAR, and Chile can be easily become a legitimation to accept the formula (Hakim et.al., 2007).

This research is dedicated to find out the impact of application of the costbased interconnection tariff to the retail tarif created by the operator.

\section{Literature Review}

\section{Service Costing in Telecommunication Industry}

Based on the "Infocom" Ministry Regulation No. 8 Year 2006 about Interconnection, the retail tariff is formulated as follow:

Retail Tariff = Cost of Network Elements + Cost of Service Activity + Margin

According to the "Infocom" Ministry Regulation No. 8 Year 2006 about Interconnection, interconnection is any connection between two or more different telecommunication network. In other words, interconnection is the only way to connect one service provider to another service provider. This connection create additional cost that called interconnection cost.

The cost of network element is determined through LRIC Bottom Up Method, as mentioned on the "Infocom" Ministry Regulation No. 8 Year 2006 about Interconnection. LRIC Bottom Up Method is added by cost of on-net network element. The addition is calculated by using routing factor or weighted on-net call traffic. Cost of service activity is total cost of performing service activity inside the operator. While 
the margin is the profit expected by operator to be added on the tariff. The margin is fully determined by the operator.

In general, there are four basic theory that explain the method of interconnection tariff determination (Harbord et.al., 2010):

a. Bill and Keep

b. Retail Prices with Discount

c. Revenue Sharing Arrangement

d. Cost-Based Interconnection

From all of the method, the method of cost-based interconnection tariff is the most widely accepted method that creates a healthy competition. The method produces an efficient and fair calculation, both to existing and new players. It used by many developing countries such as Bostwana, Jordan, and Malaysia. The method is also resulting a sufficient rate of return (ROR) to operators. There are several approaches on this method, but the most popular are:

- Fully Allocated Cost (FAC) or Fully Distributed Cost (FDC)

- Forward Looking Long Run Incremental Cost (LRIC)

The LRIC method has several approaches, i.e.:

- Long Run Average Incremental Cost (LRAIC)

- Total Element Long Run Incremental Cost (TELRIC)

- Total Service Long Run Incremental Cost (TSLRIC)

Since 2006, the calculation of interconnection tarif in Indonesia is based on LRIC method, especially TSLRIC one. With this approach, new players can determine whether using the infrastructure of existing operators or build their own facilities. This consideration come from the fact that the interconnection tariff reflects the cost of building the network, including a necessary rate of return of the investment.

\section{Cost-Plus Pricing}

Cost accounting is purposed to present cost information that will be used in the decision making. One of the decision is price determination that based on the cost information. It often called as cost-plus pricing, i.e. all (service) cost plus a determined markup (Kamaruddin Ahmad, 2005). Cost-plus pricing in telecommunication industry is also reflected on retail tariff determination. The cost information must be created to fulfill these objectives (Hansen and Mowen, 2006):

a. Costing out services, products, and other objects of interest to management

b. Planning and Control

c. Decision Making

\section{Research Method}

The method used in this research is qualitative paradigm method. The method is also known as constructive, naturalistic or interpretative approach that emphasize on the understanding of any problems in social life, based on reality condition or a holistic, complex, and detail natural setting, and using a inductive approach to construct the theory or hypotheses through fact disclosures (Indriantoro dan Sutopo, 2002).

The stage of analysis is implemented as follows:

1. Observing the social phenomenon, identification, revision, and re-check on the data available. 
2. Creating a categorization to the information gathered.

3. Doing a walkthrough and explaining the category.

4. Explains relations on the category.

5. Making a general conclusions.

Category Design

\begin{tabular}{|c|c|c|}
\hline No. & Categories & Sub-category \\
\hline 1. & Characteristic of tariff & Cost-Based interconnection tariff \\
\hline & & Retail tariff \\
\hline 2. & Strategic Benefit & $\begin{array}{l}\text { Control on Interconnection Tariff } \\
\text { Decision Making on Retail Tariff }\end{array}$ \\
\hline
\end{tabular}

\section{Results and Discussions}

\section{Characteristic of the tariff}

Interconnection cost assigned by call destination operator to origin call operator who responsible for an interconnection call. Resposibility for an interconnection call including service quality, billing process (calculation) of call services, billing charges to customer, and allowance for uncollectible bill. For instance: customer A who use service of operator $X$ calls $B$ who use service of operator $Y$. Operator $X$ acts as origin call operator and $Y$ acts as call destination operator, so operator $X$ has a responsibility for the interconnection call. Other responsibility also privided by interconnection operator that perform other interconnection services.

There are two categories in mobile interconnection services, i.e. origination interconnection and termination interconnection.

For interconnection cost billing purposes, it is based on agreemtn between operators. While for charging and billing the interconnection cost, it must be declared on the LIO. Operators have to disclose a report containing the calculation of its interconnection cost to BRTI. The report consists of:

a. Financial report to the regulator;

b. A documentation of calculation, both hard and soft copy form (soft copy report contains a formulation in form of spreadsheet); or

c. Cost allocation as determined on the Method of Cost Allocation and Financial Report to the regulator.

The report is given to BRTI at least 20 days before implementated.

Retail tariff is service tariff charged to customer which consider several aspects:

1. Component of tariff;

2. Network Services Cost (NSC);

3. Retail Services Activities Cost (RSAC);

4. Retail Services Cost (RSC) and Tariff cost.

While cost of celullar services basically consists of:

1. Network Services Cost (NSC),

2. Retail Service Activities Cost (RSAC).

NSC is cost of end-to-end On Net celullar services and interconnection cost that's 
calculated by "Infocom Ministry Regulation", ie NSC Bottom Up.

\section{Strategic Benefit of Costing System}

Todays, the role of a costing system in telecommunication industry is rising dramatically. It is caused by the tariff charged to customer is determined by a calculation formula which considers several components, ie. cost driver, cost variable, and a constanta. Tarif determination itself is pursued to gain a least two objectives, i.e.:

1. Provide an information needed to planning purposes and for decision making process.

2. As control function or tool for monitoring the how the system works.

In this case, function of decision making is used to determine retail tariff charged to customer, while control function owned by regulator is used to control the value of interconnection tariff that will become the part of retail tariff.

Control is not only dedicated to find a mistake but also designed to aviod the mistake itself and make an improvement when a mistake happened. In other words, control is embedded before the process, when the process is performing, and at the end of the process, i.e. when the final result accomplished. With control, it is expected that activities related to use of all managerial elements can be done effectively and efficiently.

BRTI who acted as a regulator in telecommunication industry has a role in implementing the control function of telecommunication services price. In this study, researcher focused on the mobile services. This illustration will demonstrate how the calculation of interconnection cost between mobile operators.

Network Operator $1(X)$ use pricing zoning where area $A$ and $B$ defined as one local area with tariff $=2$ price unit $(p u)$ per minutes. Network Operator $2(Y)$ use zoning where area $A$ and $B$ defined as two different local area with local tariff $=1 \mathrm{pu}$ per minute and inter-local tariff $A$ from/to $B=3$ pu per minute. While 1 pu equal to $R p$ 800 .

Let's analyze the strategy for $X$ and $Y$ between those two ways of interconnection, which one will generate maximum profit.

(a) Model I: user/customer is charged according to NO origination tariff, and the accounting process for interconnection is calculated according to NO origination tariff, then the termination provider get a 50\% share.

(b) Model II: user/customer is charged according to NO origination tariff, and the accounting process for interconnection is calculated according to NO termination tariff, then the termination provider get a 50\% share.

(c) Model III: user/customer is charged according to NO origination tariff, and the accounting process for interconnection is calculated for Rp.449 per minute for local calls and Rp.622 per minute for interlocal calls that should be paid by oringination NO to termination NO. The determination whether the call is a local or interlocal call is based on the system at the termination NO. 
For calculation purposes, let us see traffic volume of interconnection betweeen $X$ and $Y$, as follows:

\section{Data of Traffic Volume of Interconnection between $X$ dan $Y$}

\begin{tabular}{|c|c|c|l|c|c|c|}
\hline \multicolumn{2}{|c|}{ Origination $=\boldsymbol{X}$; Termination $=\boldsymbol{Y}$} & & \multicolumn{3}{c|}{ Origination $=\boldsymbol{Y}$; Termination $=\boldsymbol{X}$} \\
\hline & A & B & & & $A$ & B \\
\hline A & 1000 hour & 400 hour & & $A$ & 1200 hour & 900 hour \\
\hline B & 200 hour & 800 hour & & $B$ & 600 hour & 800 hour \\
\hline
\end{tabular}

\section{a.Model I:}

Before interconnection accounting:

$$
\begin{array}{llr}
\text { Income of } X & =(1000+400+200+800) * 60 * 2 \mathrm{pu} & =288000 \mathrm{pu} \\
\text { Income of } Y & =((1200+800) * 60 * 1)+((900+600) * 60 * 3) \mathrm{pu} & =390000 \mathrm{pu}
\end{array}
$$

After interconnection accounting:

$$
\begin{array}{ll}
\text { Income of } X & =\text { Income of } Y=(288000+390000) / 2=339000 p u \\
\text { Income of } X & =\text { Income of } Y=R p 271,200,000
\end{array}
$$

\section{b.Model II :}

Before interconnection accounting:

$$
\begin{array}{llr}
\text { Income of } X & =(1000+400+200+800) * 60 * 2 \mathrm{pu} & =288000 \mathrm{pu} \\
\text { Income of } Y & =((1200+800) * 60 * 1)+((900+600) * 60 * 3) \mathrm{pu} & =390000 \mathrm{pu}
\end{array}
$$

Calculation or accounting purposes, as if:

$$
\text { Income of } X^{*} \quad=((1000+800) * 60 * 1)+((200+400) * 60 * 3) p u=216000 \mathrm{pu}
$$$$
\text { Income of } Y^{*}=(1200+800+900+600) * 60 * 2 \quad=420000 \mathrm{pu}
$$

After interconnection accounting:

$$
\begin{aligned}
\text { Income of } X & =\text { Income of } X-\left(40 \% \times \text { Income of } X^{*}\right)+ \\
& \left(40 \% \times \text { Income of } Y^{*}\right) \\
& =288000-(0.4 * 216000)+(0.4 * 420000) \\
& =369600 \mathrm{pu}=R p 295,680,000 \\
& =\text { Income of } Y-\left(40 \% x \text { Income of } Y^{*}\right)+ \\
& \left(40 \% \times \text { Income of } X^{*}\right) \\
& =390000-(0.4 * 420000)+(0.4 * 216000) \\
& =308400 p u=R p 246,720,000
\end{aligned}
$$

\section{c. Model III}

Before interconnection accounting:

Income of $X=(1000+400+200+800) * 60 * 2 \mathrm{pu}=$

$$
R p 230,400,000
$$

Income of $Y=((1200+800) * 60 * 1)+((900+600) * 60 * 3) p u$

$$
=\text { Rp312,000,000 }
$$

The calculation model for interconnection accounting:

$$
\begin{aligned}
\text { Income of } X^{*} & =(1200+900+600+800) * 60 * 449 \\
& =R p 94,290,000 \\
& = \\
\text { Income of } Y^{*} & \\
((1000+800) * 60 * R p 449)+((200 & +400) * 60 * R p 622) \\
& =R p 70,884,000
\end{aligned}
$$

After interconnection accounting :

$$
\text { Income of } X \quad=\text { Income of } X \text { - Income of } Y^{*}+\text { Income of } X^{*}
$$


Income of $Y$

$$
\begin{aligned}
& =\text { Rp253,806,000 } \\
& =\text { Income of } Y-\text { Income of } X^{*}+\text { Income of } Y^{*} \\
& =\text { Rp288,594,000 }
\end{aligned}
$$

The following table is a list of NO's revenue from each calculation model of interconnection tariff:

NO's Revenue from Several Interconnection Model

\begin{tabular}{|c|c|c|}
\hline \multicolumn{3}{|c|}{ Income Calculation } \\
\hline & Operator $\boldsymbol{X}$ & Operator $\boldsymbol{Y}$ \\
\hline Revenue from Retail Services & $230,400,000$ & $312,000,000$ \\
\hline \multicolumn{3}{|c|}{ Operator's Revenue: } \\
\hline Model I & $271,200,000$ & $271,200,000$ \\
\hline Model II & $295,680,000$ & $246,720,000$ \\
\hline Model III & $253,806,000$ & $288,594,000$ \\
\hline
\end{tabular}

For Operator X, the highest revenue is received when using model 2. While for Operator Y, the highest revenue should be arrived from the use of Model 3. When using Model 1, each operators gain an equal revenue. Meanwhile, is Model 1 the most fair way in revenue sharing? The answer is not always. Because if we look at the traffic volume of interconnection above, the customer of Operator $Y$ has a higher traffic than the customer of Operator X. Thereby, it would be unfair if both operator $X$ and $Y$ received the same amount of money.

Model 2 is absolutely an unfair model because Operator X with lower traffic of customer use will get a higher income. Model 3 is seems to be a closer model to the fairness in profit sharing, because Operator $Y$ gain a higher profit, as of Operator $Y$ has a higher in its traffic volume. This method is implemented in Indonesia.

From all of the illustration given, we can find out the impact of interconnection tarif to the revenue of an operator. A different system in interconnection tarif will usually influence the amount of operator's revenue. Then it will be important to an operator to formulate its interconnection tarif in accordance with its marketing strategy based on the number of customers and the character of traffic. Obviously, major operator has a different marketing strategy compared to other operator that have a less customer.

Todays, many operators trying to increase their market share by reducing their retail voice tariff especially the tariff for inter-operator call service. Inter-operator voice call tariff is reduced dramatically with several variations of tariff. It can be easily done because of there is no interconnection tariff between different operators. This action is also taken for promotion purposes, in order to gain more customer and finally to increase their revenues.

Thereby, cost information will be needed to produce several reports, the reports that will be useful for telecommunication industry to make a decision in pricing or retail tariff determination. Decision making of pricing is based on effectivity and the availability of components information. As we've find out, the components of retail tariff consists of network element costs (cost-based interconnection tariff), costs of retail service activity and a margin.

In logical term, component of interconnection tariff causes a decrease on selling price/retail tariff to customer. However, it will not directly reduce the operator's revenue. In general, they will earn a higher revenue generated from the increasing number of customers, as illustrated here: 
where:

After implementing cost-based interconnection tariff

$\begin{array}{llll}\boldsymbol{P} \downarrow & \boldsymbol{X} & \boldsymbol{Q}\end{array}$

P: Price (selling price/retail tariff)

Q: Quantity (number of customers)

R: Revenue

This formula will endorse the operators to set their minimum tariff as a maximum tariff (the most expensive tariff charged to customers), until the selling price/retail tariff charged to customers become cheaper and cheaper. Customers will be attracted to use their services and more telecommunication companies will compete in a fair competition market. Finally, this effort will encourage a sustainable growth for Indonesian telecommunication sector.

\section{Strategic Benefit of Interconnection Tariff}

Strategic benefit generated from the implementation of costing system in telecommunication industry might be viewed from two aspects, i.e. control aspect and decision making process with a focus to cost aspect. A summary of the implementation of costing system in Indonesian telecommunication sector will be presented by the following table:

Strategic Benefit of Costing System at BRTI and PT. Indosat, Tbk.

\begin{tabular}{|c|c|}
\hline Control & Decision Making \\
\hline $\begin{array}{l}\text { 1. An implementation of interconnection } \\
\text { tariff based on cost-based maximum } \\
\text { tariff (for customer interest). } \\
\text { 2. An establishment of regulatory body }\end{array}$ & $\begin{array}{l}\text { 1. A determination of retail tariff } \\
\text { based on effectivity and and the } \\
\text { availability of components } \\
\text { information. }\end{array}$ \\
\hline $\begin{array}{l}\text { which control and monitor the } \\
\text { interconnection tariff determination } \\
\text { in order to reach a fair competition. }\end{array}$ & $\begin{array}{l}\text { 2. Cost information is needed to } \\
\text { determine the selling price/retail } \\
\text { tariff charged to customer. }\end{array}$ \\
\hline $\begin{array}{l}\text { 3. An establishmet of performance } \\
\text { report such as List of Interconnection } \\
\text { Offer (LIO). }\end{array}$ & $\begin{array}{l}\text { 3. To allocate or pool a cost based } \\
\text { on the real retail activity. }\end{array}$ \\
\hline
\end{tabular}

\section{Conclusion and Recommendation}

A conclusion to this study might be derived from a simple formula of cost-based calculation, as described above. It can be concluded that by using the method, the word "fair" has been sufficiently realized between two or more interconnected operators. In addition, the strategic benefit of costing system might be viewed as a control tool for running the operation of telecommnication industries in Indonesia to promote customer's interest, fair competition, and efficiency. While the strategic benefit of costing system in decision making reflects an effect of cost-based interconnection tariff as part of retail tariff to customers. Selling price or retail tariff is become cheaper. This interconnection tariff system causes also a change in cost allocation in operators. Cost allocation has become more related to its retail activity. 
The authors suggests the government or regulator to implement a sufficient monitoring and evaluation system for controlling the maximum value of interconnection tariff. This monitoring system, however, will be useful to make sure that the operators will follow the rule. While the evaluation system is needed to make a regular improvement on the costing system based on an available and accurate related information. Those mechanisms might promote a sustainable growth and development in telecommunication industry.

\section{References}

Ahmad, Kamaruddin. 2005. Akuntansi Manajemen: Dasar-dasar Konsep Biaya dan Pengambilan Keputusan. Jakarta: Raja Grafindo Persada.

Arif Rahman Hakim. 2007. Analysis of Interconnection Tariff between Network Operators in Indonesia. Bandung Institute of Technology (ITB), Central Library.

Blocher, Edward J; Kung H. Chen; Gary Cokins \& Thomas W. Lin. 2005. Cost Management: A Strategic Emphasis third edition. New York: McGraw-Hill.

Bogdan and Taylor. 1975. Introduction to Qualitative Research Method. New York : John Willey and Sons, 1975.

Burhan, Bungin, 2007, Penelitian Kualitatif untuk Komunikasi, Ekonomi, Kebijakan Publik dan Ilmu Sosial Lainnya. Prenada Media Group. Jakarta.

Denzin and Lincoln. 1987. (eds.). Handbook of Qualitative Research, Sage, Thousand Oaks, 1994.

Dicky R. Munaf, 2008. Information Interconnection for Communication Strategy of Iptek Products. Bandung Institute of Technology (ITB), Central Library.

Fina Ginting. 2008. A Saving on Total Interconnection Tariff from Shared-Us of Telkom Satellite Tower. Bandung Institute of Technology (ITB), Central Library.

Hansen, Don R. \& Maryanne M. Mowen. 2006. Cost Management Accounting and Control fifth edition. Ohio: South Western.

Harbord, David \& Marco Pagnozzi. 2010. Network-Based Price Discrimination and 'Bill-and-Keep' vs. 'Cost-Based' Regulation of Mobile Termination Rates. MPRA Paper 14540, University Library of Munich, Germany.

Horngren, Charles T.; Srikant M. Datar; Geoge Foster; Madhav Rajan \& Christoper Ittner. 2009. Cost Accounting: A Managerial Emphasis $13^{\text {th }}$ Ed. New Jersey: Prentice Hall.

Indonesian Institute of Accountants. 2009. Financial Accounting Standards. Jakarta: Penerbit Salemba Empat.

Kennet, D. Mark \& Eric K. Ralph. 2007. Efficient Interconnection Charges and Capacity-Based Pricing. USA: George Mason University.

Keputusan Menteri Perhubungan No. KM 72 Tahun 1999 tentang Struktur Jasa Telekomunikasi.

Keputusan Menteri Perhubungan No. KM 31 Tahun 2003 tentang Penetapan Badan Regulasi Telekomunikasi Indonesia.

Keputusan Menteri Perhubungan No. KM 67 Tahun 2003 tentang Tata Hubungan Kerja antara Departemen Perhubungan dengan Badan Regulasi Telekomunikasi Indonesia. 
Lampiran 1 PM Kominfo No. 8 Tahun 2006 tentang Metode Perhitungan Biaya Interkoneksi.

Lampiran 2 PM Kominfo No. 8 Tahun 2006 tentang Metode Pengalokasian Biaya dan Laporan Finansial Kepada Regulator.

Lampiran 3 PM Kominfo No. 8 Tahun 2006 tentang Besaran Biaya Interkoneksi.

Lampiran 3 PM Kominfo No. 9 Tahun 2008 tentang Tata Cara Perhitungan Tarif Jaringan Bergerak Selular.

Lampiran 4 PM Kominfo No. 8 Tahun 2006 tentang Petunjuk Penyusunan Dokumen Penawaran Interkoneksi (P2DPI).

Lampiran 4 PM Kominfo No. 9 Tahun 2008 tentang Tata Cara Pelaksanaan Pengawasan dan Pengendalian Terhadap Penetapan Tarif Pungut Layanan Jasa Telekomunikasi Melalui Jaringan Bergerak Selular.

Lampiran Keputusan Dirjen Pos dan Telekomunikasi Tahun 2005 tentang Petunjuk Perhitungan Biaya Interkoneksi Model Jaringan Bergerak Bottom-Up.

Lexy, J. Moleong. 2005. Metodologi Penelitian Kualitatif Edisi Revisi. Bandung: PT Remaja Rosdakarya.

Peraturan Menteri Komunikasi dan Informatika No. 8 Tahun 2006 tentang Interkoneksi.

Peraturan Menteri Komunikasi dan Informatika No. 9 Tahun 2008 tentang Tata Cara Penetapan Tarif Jasa Telekomunikasi Yang Disalurkan Melalui Jaringan Bergerak Selular.

Peraturan Pemerintah No. 8 Tahun 1993 tentang Penyelenggaraan Telekomunikasi.

Peraturan Pemerintah No. 52 Tahun 2000 tentang Penyelenggaraan Telekomunikasi Umum.

Rohyani Gofar. 1998. Decision Support System for Interconnection Tariff Determination between Celullat Network and PSTN. Bandung Institute of Technology (ITB), Central Library.

S. Verbrugge, B. Lanoo, J. Van Ooteghem, T. Pignet, D. Colle, M. Pickavet, P. Demeester, 2006. "Regulation for Interconnection Between Network Operators in a Liberalised Market". IADIS International Conference WWW/Internet 2006, Proceeding.

2006. Interkoneksi dan Dampak Terhadap Bisnis Telekomunikasi. Majalah SDA.

2006. Interkoneksi dan Reformasi Telekomunikasi. Majalah Rempoa.

Sucipto. 2004. Penerapan Akuntansi Manajemen dalam Pengambilan Keputusan. USU Digital Library.

Sugiyono. 2005. Memahami Penelitian Kualitatif. Bandung: Alfabeta. 2010. Metode Penelitian Kuantitaif Kualitatif dan R\&D. Bandung: Alfabeta.

Undang Undang No. 36 Tahun 1999 tentang Telekomunikasi.

Wilson, James D \& James P. Colford. 1990. Controllership: The Work of Managerial Accountant ( $4^{\text {th }}$ Edition). New Jersey: John Willey and Son Inc.

Wright, J. 2002. "Bill and Keep as The Efficient Interconnection Regime?", Review of Network Economics, Vol.1, pp. 54-60.

Zeithaml, Valarie A.; Mary Jo Bitner \& Dwayne D. Gremler. 2006. Services Marketing: Integrating Customer Focus Across The Firm 4e. New York: McGraw Hill.

Zimmerman, Jerold L. 2008. Acconting for Decision Making and Control, $6^{\text {th }}$ edition. New York: McGraw Hill.

http://www.brti.or.id/ (accessed: 11 Februari 2010)

http://www.postel.go.id/ (accessed: 11 Februari 2010) 